\title{
Současná podoba environmentální výchovy a její potenciál v ovliv- ňování environmentálního uvědomění žáků
}

\author{
Eliška Sokolíková, Jan Andreska \\ Envigogika 16 (2) - Recenzované články / Reviewed articles
}

Published/ Publikováno 30. 12. 2021

DOI: $\underline{10.14712 / 18023061.632}$

\begin{abstract}
Abstrakt
Článek představuje výsledky výzkumu, který se zabýval analýzou environmentálního vzdělávání žáků středních škol s důrazem na prozkoumání faktorů ovlivňujících pro-environmentální chování. Výzkum využívá model sestavený na základě metody TPB (Theory of Planned Behavior) a metody NAM (Norm Activation Model). Z analýzy je patrné, že značná část žáků považuje současnou environmentální výchovu za nedostatečnou. Nejčastějším zdrojem informací se v oblasti environmentálního vzdělávání stává pro žáky internet a sociální sítě. Stěžejním determinantem pro-environmentálního chování jsou dle výsledků výzkumu postoje a normy respondentů, které je možné v rámci environmentálního vzdělávání ovlivnit skrze budování povědomí o důsledcích chování. Článek se také vzhledem k odlišným výsledkům jednotlivých zahraničních studií obdobného zaměření zamýšlí nad důležitostí lokálního výzkumu v oblasti rozvoje environmentálního vzdělávání, který je v oblasti analýzy determinantů environmentálního uvědomění stále na samém začátku.
\end{abstract}

\section{Klíčová slova}

environmentální vzdělávání, environmentální výchova, environmentální uvědomění, pro-environmentální chování, Teorie plánovaného chování, TPB, NAM

\begin{abstract}
The article presents the results of a study that examined the environmental education of high school students, with a focus on examining the factors that influence environmentally friendly behavior. The research uses a model based on the TPB method (Theory of Planned Behavior) and the NAM method (Norm Activation Model). The analysis shows that a significant number of students consider current environmental education to be insufficient. The Internet and social networks become the most common source of information for students in the field of environmental education. According to the results of the research, the most important determinants of environmentally friendly behavior are the attitudes and personal norms of the respondents, which can be influenced in the framework of environmental education by creating awareness of the consequences of behavior. Due to the different results of individual foreign studies with a similar focus, the article also considers the importance of local research in the field of environmental education development, which is still in its infancy in the field of analysis of the determinants of environmental awareness.
\end{abstract}

\section{Key words}

environmental education, environmental awareness, pro-environmental behavior, Theory of Planned Behavior, TPB, NAM 
Z mnoha stran se k nám v současné době dostávají informace o problémech životního prostředí a neudržitelnosti stávajícího stavu a předpokládaného trendu. Neustálý nárůst odpadu, který nezvládáme efektivně zpracovávat nebo to $v$ prípadě některých jeho složek prozatím ani neumíme, enormní produkce skleníkových plynů a dalších látek narušujících ovzduší, zásahy do prostředí kvůli rozšiřování infrastruktury, neuvážená těžba a využívání neobnovitelných zdrojů energie, plýtvání jídlem, obrovské škody $v$ oceánských biotopech způsobené plastovým odpadem nebo klimatická změna, na kterou vědci upozorňují již mnoho let a kterou není možné nadále přehlížet a spekulovat o její existenci je jen výčtem několika hlavních environmentálních problémů současnosti. Ve skutečnosti bychom zásadních problémů ohrožujících stav životního prostředí našli mnohem více, ale pro účely tématu environmentálního vzdělávání to není až tak důležité. Zcela zásadní je pro nás ale fakt, že většina těchto globálních problémů má jednu společnou přičinu. A tou je chování nás lidí.

Je tedy zřejmé, že pokud si přejeme, aby $v$ oblasti ochrany životního prostředí nastala změna a další rozvoj byl udržitelný, musíme environmentální vzdělávání a výchovu budoucích generací zařadit mezi naše priority. Současně však musíme získat informace o tom, jak co nejefektivněji toto vzdělávání naplánovat a obsahově přizpůsobit stávající situaci. Jedině tak budeme schopni dosáhnout změn v chování lidí k životnímu prostředí.

Abychom mohli odhalit, jak žáci středních škol (toto označení respondentů volíme podle Strakové (2021) přistupují k environmentálním problémům (tedy jak je vnímají, jaké mají v této oblasti znalosti a jaké je jejich následné chování $k$ životnímu prostředí), zkoumáme $v$ rámci našeho výzkumu jejich pro-environmentální chování a faktory, které na něj mohou mít vliv. Vycházíme z předpokladu, že $k$ tomu, abychom mohli $v$ rámci vzdělávání toto chování (a obecně environmentální uvědomění) záměrně zvyšovat, musíme nejdřive dobře porozumět mechanismům jeho ovlivňování. $V$ rámci výzkumu se proto žáků ptáme, z jakých zdrojů a jakou formou se k nim informace o environmentální problematice dostávají a jakou roli hraje $v$ seznamování s touto problematikou jejich škola. Pomocí sady otázek sestavených na základě metody TPB (Theory of Planned Behavior - Teorie plánovaného chování) se taktéž snažíme zmapovat vnímané vnitřní a vnější překážky v cestě za ohleduplným chováním k životnímu prostředí.

\section{Environmentální uvědomění a možnosti jeho ovlivnění}

$\checkmark$ př́padě environmentálního uvědomění se zaměřujeme celistvě na osobnost jedince $z$ hlediska jeho postojů, ale především na jeho chování v oblasti ochrany životního prostředí a udržitelného rozvoje.

Çokçaliskan a Çelik (2017) definují environmentální uvědomění jako přesvědčení daného jedince o environmentálních aktivitách a problémech, které vyústúuje $v$ určité behaviorální záměry a následné pro-environmentální chování. V českém prostředí je často užíváno termínu environmentální gramotnosti s různým výkladem jednotlivých autorů. Někteří autoři (Činčera a Kroufek, 2021, Svobodová, 2018) pracují s termínem environmentální gramotnost v tom smyslu, že pod termín zahrnují dimenzi kognitivní, konativní i afektivní. Naopak Matějček a Bartoš (2012) uvádí, že environmentální gramotnost je chápána spíše jako soubor znalostí, dovedností a postojů. $\vee$ tomto článku se přikláníme $\mathrm{k}$ pojmu environmentálního uvědomění, které v sobě zahrnuje veškeré zmíněné proměnné, a kromě nich se vždy soustředí také na zkoumání a analýzu pro-environmentálního chování a důvody jeho konečné podoby. Vycházíme z pojmu environmental awareness, který je v zahraničních studiích $v$ tomto ohledu již zavedeným a dobře aplikovatelným termínem pro účely našeho výzkumu (Bai a kol., 2020, Fu a kol., 2020, Long a kol., 2020, Rustam a kol., 2020, Situmorang a Tarigan, 2018, Yang a kol., 2021).

Faktorů, které mohou ovlivňovat environmentální uvědomění existuje celá řada. Všichni jsme ovlivňováni svým okolím a z výzkumného hlediska je pro nás stěžejní zjistit, které faktory nejvíce ovlivňují naše konečné pro-environmentální chování, kterým my jako společnost nejvíce ovlivňujeme 
životní prostředí kolem nás. Environmentální uvědomění a především tedy pro-environmentální chování může být dle dosud provedených výzkumů ovlivněno znalostmi, které o konkrétních environmentálních problémech máme a na jejichž základě upravujeme své behaviorální záměry (Arı a Yılmaz, 2017, Çokçaliskan a Çelik, 2017, Wihardjo a kol., 2017), vztahem k př́rodě, především tehdy, pokud jsme si silné a pozitivní pouto $k$ prírodě vybudovali již v raném dětství (Ärlemalm-Hagsér, 2013, Chawla, 1998, Ewert a kol., 2005). Environmentální uvědomění může být také ovlivněno soubory faktorů, se kterými se setkáváme $v$ rámci rodiny, školy nebo mediálních prostředků jako je internet a sociální sítě, televize, tisk atd. (Çokçaliskan a Çelik, 2017, Nagra, 2010, Wihardjo a kol., 2017, Zhongguo, 2004).

\section{Metodika}

Článek představuje pilotní výzkum, do nějž bylo zahrnuto 71 respondentů 1. a 2. ročníků středních škol z České republiky. Pro výzkum byl zvolen kvantitativní výzkumný design a v budoucnu je plánováno sesbírání většího množství dat pro podrobnější analýzu dané problematiky. Základ zkoumání položil předchozí kvalitativní výzkum zabývající se srovnáním environmentálního uvědomění žáků z tradičních a alternativních základních škol (Sokolíková, 2019). Výzkum poukázal na řadu otázek, které si v této problematice zasluhují větší pozornost a důkladnější prozkoumání.

Dotazník obsahoval celkem 84 otázek a byl členěn na jednotlivé logické celky. Rozsahem největší byla část dotazníku sestavená na základě metody TPB (Theory of Planned Behavior, v českém prostředí známá jako Teorie plánovaného chování) a metody NAM (Norm Activation Model), které nám pomocí specializovaných otázek pomáhají prozkoumat vnímané vnitřní a vnější hybné síly ovlivňující konečné pro-environmentální chování žáků.

Autorem metody TPB je Icek Ajzen, sociální psycholog a emeritní profesor, který předpokládá, že lidské chování je $v$ konečném důsledku ovlivněno souborem několika na sobě závislých faktorů. Mezi tyto faktory řadí postoje založené na přesvědčení o možných dopadech zamýšleného chování, subjektivní normy zahrnující postoje ostatních blízkých účastníků v rozhodovacím procesu, a nakonec vlastní kontrolu chování představovanou vírou ve schopnost určité jednání uskutečnit. Jednotlivé faktory na sebe vzájemně působí a skrze vytvoření určitého behaviorálního záměru pak vedou ke konkrétnímu chování. Metoda TPB je již řadu úspěšně využívána k výzkumu v oblasti lidského chování a využívá se taktéž pro objasnění environmentálního chování ve specifických situacích, především však v zahraničí (De Leeuw a kol., 2015, Greaves a kol., 2013, Poškus, 2018). výzkumy v environmentální oblasti v České republice $s$ využitím této metody jsou zatím spiše ojedinělé.

Metodu NAM navrhl sociální psycholog Shahlom H. Schwartz (1977) za účelem vysvětlení prosociálního a pro-environmentálního chování. Model popisuje osobní normy jedince, které předurčují jeho konkrétní chování v dané situaci. Osobní normy jsou pak aktivovány dvěma hlavními faktory uvědoměním si důsledků svého chování a převzetím zodpovědnosti za dané chování.

Některé výzkumy (Wang a kol., 2019) využívají NAM samostatně, nicméně stále častěji se setkáváme $s$ využitím NAM v kombinaci s některou $z$ dalších metod. Studie zabývající se vysvětlením environmentálního uvědomění často kombinují NAM s TPB, př́kladem mohou být studie Chen (2020), Esfandiar a kol. (2020) nebo Park a Ha (2014), přičemž nově sestavené výzkumné modely zpravidla využívají jen některé položky původních modelů. Stejně tak je tomu v př́padě našeho výzkumu. Metoda TPB, pomocí které jsme sledovali postoje, subjektivní normy a vnímanou kontrolu chování, byla doplněna o dvě hlavní položky vycházející z metody NAM - o osobní normy a uvědomění si důsledků chování. Zdrojem inspirace pro zmíněnou skladbu dotazníku byla studie Esfandiar a kol. (2020), která s úspěchem využívala právě tuto kombinaci výzkumných modelů TPB a NAM a zabývala se zkoumáním pro-environmentálního chování s konkrétním zaměřením na nakládání s odpadem.

Jak uvádí př́mo tvůrce metody TPB, Icek Ajzen (1991), model Teorie plánovaného chování je vhodné obohacovat $v$ konkrétních výzkumných otázkách o další proměnné, které mohou mít na konečné chování vliv (obohacený model TPB využíval ve své studii např́klad Emekci (2019). V rámci 
našeho výzkumu jsme proto zvolili rozšíření stávajícího modelu TPB o model NAM, který má k problematice pro-environmentálního chování velmi blízko a je $s$ úspěchem $v$ environmentální tématice již řadu let využíván.

V rámci modelu TPB jsme po vzoru zmíněné studie (Esfandiar a kol., 2020) také přistoupili k úpravě jedné z položek. Oproti původní podobě modelu nejsou respondenti tázáni na záměry svého budoucího chování, ale otázky jsou formulovány s ohledem na konkrétní projevy pro-environmentálního chování jednotlivých respondentů v aktuálním čase a v konkrétních situacích. Využití skutečného (respektive respondenty deklarovaného) chování namísto pouhého záměru k tomuto chování, se jeví jako vhodné především z důvodu lepší uchopitelnosti pro žáky a možnosti získání přesnějších výsledků $v$ rámci tohoto ukazatele.

Dotazník obsahoval 5 obecných demografických otázek, 12 otázek týkajících se environmentálních témat a četností kontaktu respondentů $s$ těmito tématy $v$ běžném životě/ve škole (zájem a aktivní vyhledávání informací o konkrétní environmentální tematice, podoba environmentálního vzdělávání konkrétní školy, vztah $\mathrm{k}$ přírodě, outdoorové aktivity $\mathrm{v}$ rámci vyučování i ve volném čase atd.), 66 otázek sestavených na základě modelů TPB a NAM využívajících čtyřstupňovou Likertovu škálu odrážející míru souhlasu s danými tvrzeními a na závěr 1 otevřenou otázku k vyjádření názoru žáků na současnou podobu environmentálního vzdělávání, se kterým se setkávají ve škole. $V$ rámci šetření byla zvolena Likertova škála o čtyřech stupních s následujícími položkami - rozhodně ano, spíše ano, spíše ne, rozhodně ne.

K vyhodnocení části výzkumu, která využívala kombinaci TPB a NAM modelu, byla využita metoda PLS-SEM. Podrobnosti týkající se vyhodnocení a využitého programu jsou uvedeny $v$ kapitole Analýza pro-environmentálního chování žáků.

Ostatní otázky dotazníku byly vyhodnoceny základními metodami popisné statistiky a s jejich výsledky seznamujeme čtenáře $v$ následujících kapitolách. Kapitola je vždy uvedena krátkým teoretickým úvodem, který představuje vhled do dané problematiky a současného stavu poznání $v$ této oblasti, za kterým následuje popis výsledků, ke kterým jsme dospěli v rámci našeho výzkumu.

\section{Současné environmentální problémy a informovanost žáků v této oblasti}

Současný svět se potýká s celou řadou environmentálních problémů, které znamenají hrozbu pro další vývoj naší planety. Stejně jako školní vzdělávání odráží současný stav vědění v ostatních oborech, je na místě, aby i environmentální vzdělávání odráželo skutečné problémy a otázky, se kterými se $v$ současnosti potýkáme. Mezi témata, kterým je $v$ současnosti věnována pozornost odborníků zabývajících se stavem životního prostředí, patří například klimatické změny, problematika nadprodukce odpadu, konkrétně pak specifické problémy doprovázející plastový odpad v pevninských a především oceánských ekosystémech, plýtvání jídlem, problémy s nedostatkem pitné vody, odlesňování a mnoho dalších.

Následující graf (Graf 1) ukazuje, jak žáci interagovali s předloženou sadou několika základních environmentálních problémů a kolik z nich se $s$ těmito tématy opakovaně setkalo a má o nich povědomí. Širší povědomí žáků o environmentální problematice pak bylo patrné z odpovědí na další otevřenou otázku, ve které žáci měli možnost vypsat další témata, o kterých slýchají nebo se o ně aktivně zajímají. Mezi častěji zmiňovaná patřilo odlesňování, tání ledovců, nevyhovující podmínky chovu zviŕăt, chemické znečištění vody a objevovala se i velmi aktuální témata jako znečištění prostředí ochrannými pomůckami jako jsou roušky, rukavice a respirátory. 


\section{Povědomí žáků o environmentálních problémech}

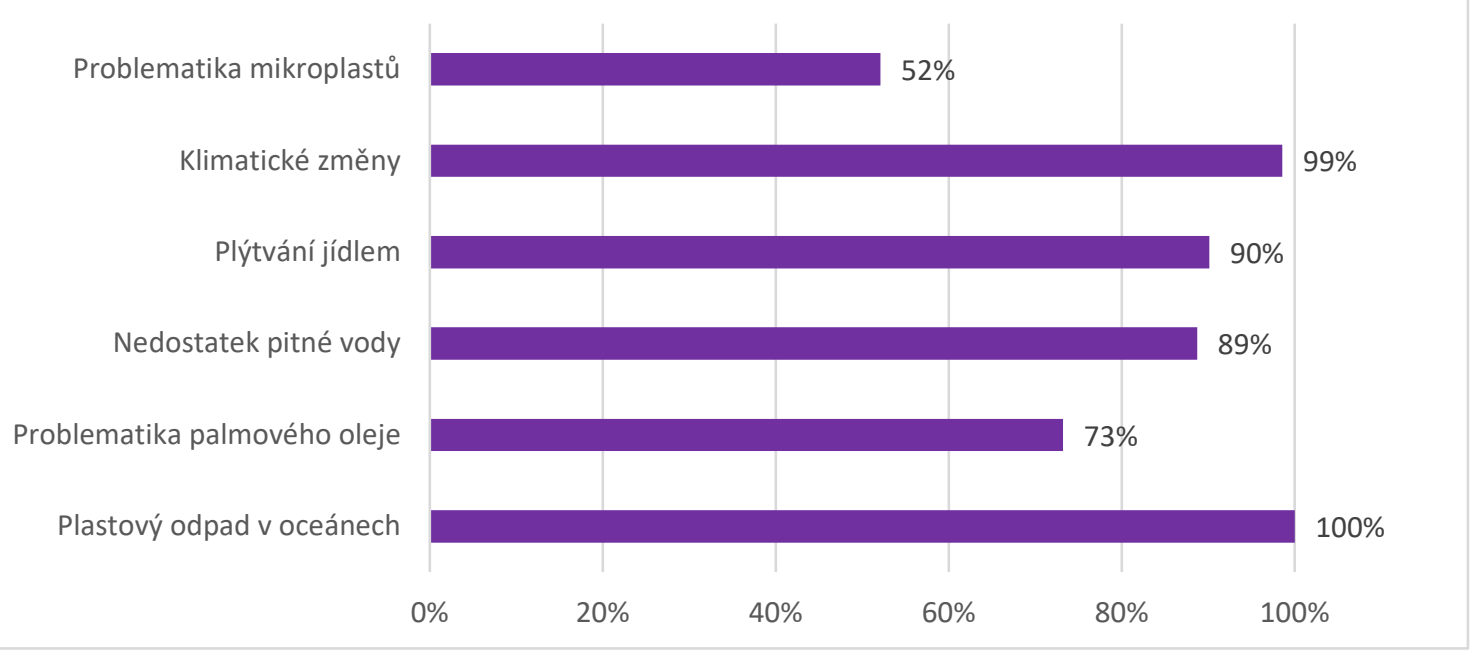

Graf 1: Povědomí o environmentálních problémech (relativní četnosti, $n=71$ )

Graf 2 pak znázorňuje, odkud se žáci o zmíněných environmentálních tématech dozvídají. Přičemž si můžeme všimnout, že zcela jasné prvenství mají podle vyjádření žáků sociální sítě a internet. Školu jako zdroj informací $v$ tomto ohledu uvedla přibližně polovina dotazovaných žáků a škola tak podle vyjádření žáků představovala častější zdroj informací než např́ílad rodina.

\section{Z jakých zdrojů se žáci dozvídají o environmentálních problémech?}

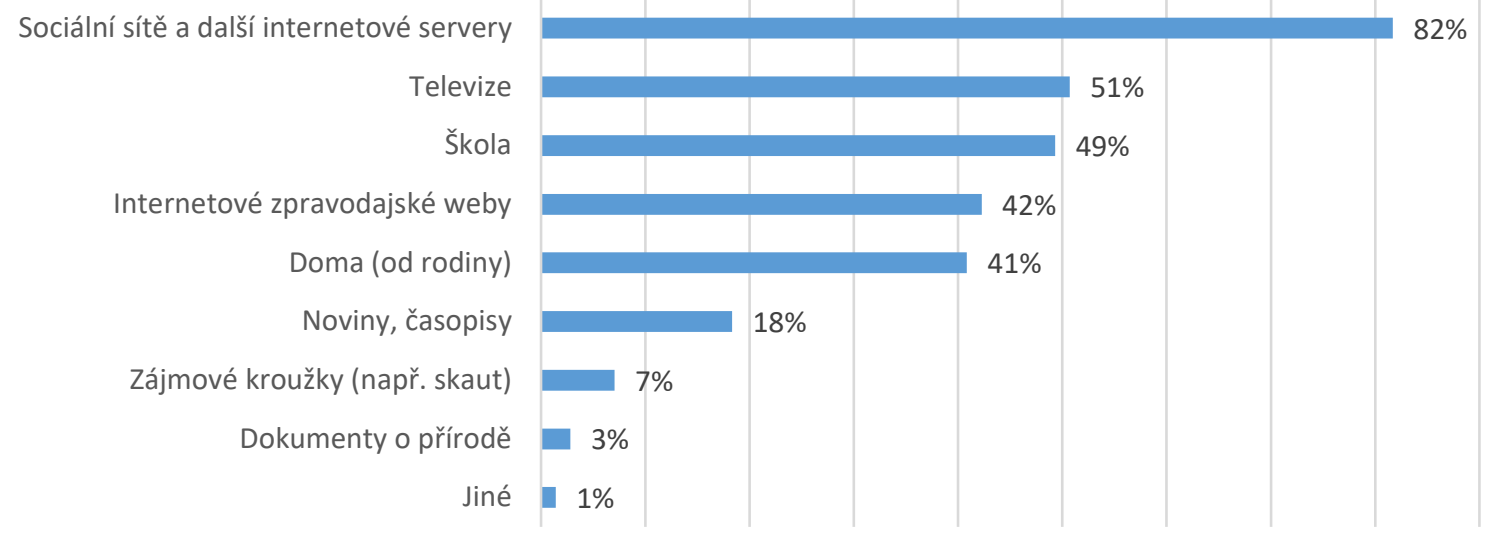

Graf 2: Zdroje informací o environmentálních problémech (relativní četnosti, n=71)

\section{Environmentální vzdělávání ve školách}

$\checkmark$ rámci dotazníku byli respondenti dotazováni na několik otázek týkajících se podoby environmentálního vzdělávání, se kterým se oni sami setkávají ve škole. Následující graf (Graf 3) znázorňuje, $\checkmark$ jakých předmětech se $s$ tematikou ochrany životního prostředí žáci nejčastěji setkávají. Čtyřicet procent dotazovaných žáků se nepřiklonilo $k$ žádné $z$ konkrétněji vymezených předmětových skupin a uvedlo, že se $s$ informacemi o tomto tématu setkávají $v$ různých předmětech napříc vzdělávacím plánem. $Z$ odpovědí žáků, kteří se k některé $z$ předmětových skupin přiklonili, nemůžeme vyvodit 
obecné závěry o tom, jaká skupina předmětů převládá. Výsledky spíše ukazují na určitou vyrovnanost mezi předměty humanitními a př́rodovědnými. Větší část žáků sice uvedla, že se tyto informace dozvídá častěji $v$ humanitních předmětech a méně pak $v$ předmětech prírodovědných, ale část žáků pak uvedla, že se s touto tématikou seznamuje výhradně $v$ rámci hodin biologie/př́rodopisu. Nemalá část žáků také uvedla, že se s těmito tématy nesetkávají v rámci žádného ze svých školních předmětů.

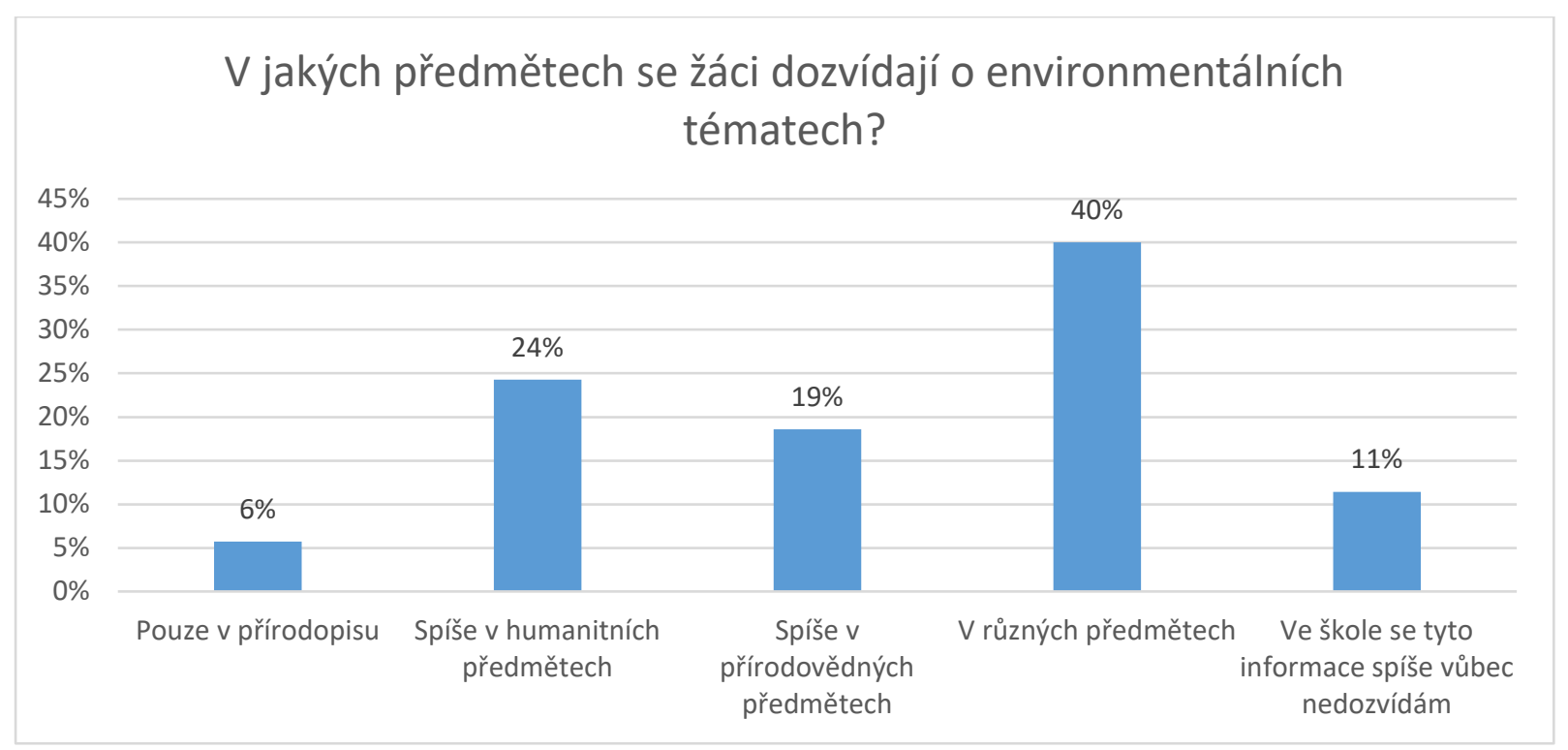

Graf 3: Školní předměty a jejich zaměření na environmentální tematiku (z pohledu žáků) - graf relativních četností $(n=70)$

Další z otázek byla cílena na subjektivní vnímání žáků ohledně dostatečnosti environmentálního vzdělávání a žáci v ní byli dotazováni, zda jim připadá, že je ve škole tématům ochrany životního prostředí věnován dostatek času. Nadpoloviční většina žáků (60 \%) vnímá environmentální vzdělávání jako nedostatečné nebo zcela nedostatečné. Pouze 4 \% žáků jsou pak zcela spokojena s obsahem environmentálního vzdělávání. Lépe žáci hodnotili environmentální vzdělávání pouze v oblasti nakládání $s$ odpadem. $V$ tomto př́padě $60 \%$ dotazovaných žáků uvedlo, že jsou $s$ výchovou $v$ této oblasti spokojeni, 40 \% žáků zastávalo názor, že je v tomto ohledu škola nevzdělává dostatečně.

Dotazník obsahoval také otevřenou otázku, ve které se žáci měli možnost rozepsat o konkrétních podnětech, kterými by rádi doplnili environmentální vzdělávání ve své škole. Nejčastěji žáci uváděli, že by měli zájem se o environmentálních tématech dozvídat ve škole více informací a uvítali by, kdyby je škola $v$ uvědomělém chování více motivovala. Žáci uváděli, že mají zájem dozvídat se více informací nejen $v$ rámci výuky, ale uvítali by i obohacení výuky uspořádáním přednášek a pozvání odborníků, kteří se této tematice věnují. $V$ odpovědích zaznívala také doporučení, aby bylo žákům jasněji vysvětleno, že odpad nelze téměř nikdy zrecyklovat stoprocentně a vždy je lepší dbát na to, aby odpad zbytečně nevznikal, tedy aby třídění odpadu nebylo považováno za dostačující řešení současné situace. Žáci by taktéž chtěli dostat ve škole informace o tom, jak mohou oni sami přispět ke zlepšování současné situace a jak mohou do budoucna přispět $k$ předcházení dalším environmentálním problémům. Mezi často zmiňovaná témata pak patřila také oblast školního stravování, at' už se jednalo o nabídku svačin nebo obědů, kdy žáci uváděli, že nejsou spokojeni se současnou situací především z hlediska plýtvání jídlem nebo nadbytku plastových obalů a rádi by, aby škola $\mathrm{k}$ těmto tématům přistupovala zodpovědněji. 


\section{Vztah žáků k přírodě a jeho podpora ze strany školy}

Důležitost budování vztahu k přírodě jako součást rozvíjení environmentálního uvědomění ve své práci uvádí hned několik autorů (Ärlemalm-Hagsér, 2013, Chawla, 1998, Ewert a kol., 2005, Nisbet a kol. 2009). Je zřejmé, že kladný vztah k př́rodě napomáhá empatii a člověk bude mít tendenci spíše ochraňovat spiše to, co má rád a je pro něj důležité než něco, k čemu nechová žádný silný vztah.

Téměř všichni žáci $(98,6 \%)$ vnímají prírodu jako důležitou součást svého života, $83 \%$ žáků vyjádřilo naprostý souhlas s tvrzením „Mám rád/a přírodu a je pro mě důležitá.". Pouze 25,7 \% žáků by si pro trávení volného času vybralo raději město než př́rodu.

Přesto, jak výzkum ukazuje, školy nezařazují vycházky do přírody do vyučování př́liš často a stejně tak většina škol neumožňuje dětem trávit volný čas v průběhu vyučování (přestávky) venku. Vycházka do prírody je velmi výjimečnou událostí pro $66,2 \%$ respondentů a pouze 31,4 \% žáků uvedlo, že jim škola pravidelně umožňuje trávit přestávky venku.

Následující graf (Graf 4) znázorňuje, jak často chodí žáci na vycházky do prírody ve svém volném čase. Pro srovnání jsou v grafu vyobrazeny zvlášt́ žáci, kteří bydlí ve městě a žáci, kteří bydlí na vesnici.

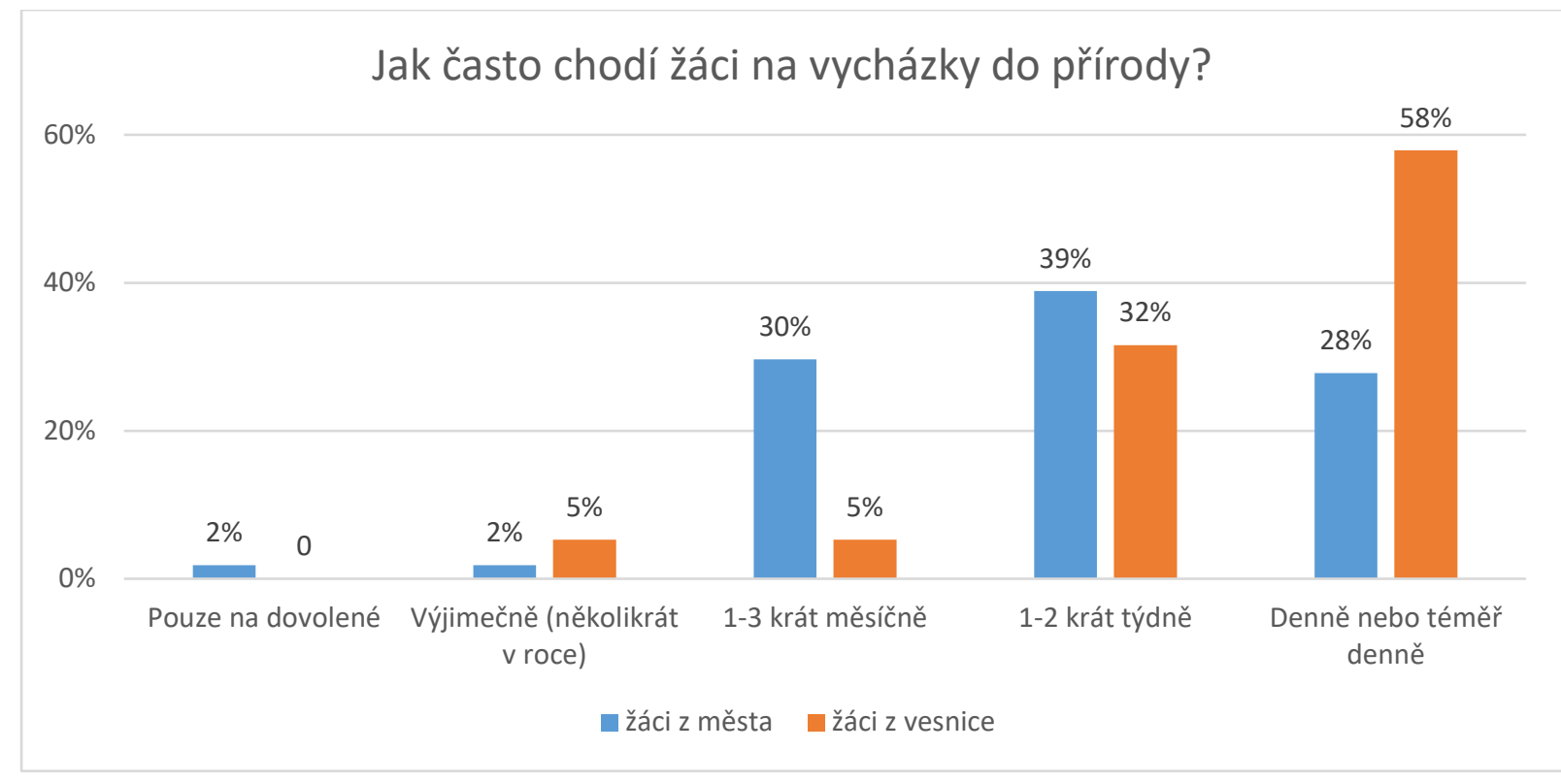

Graf 4: Frekvence vycházek do př́rody - graf relativních četností ( $n_{\text {město }}=54, n_{v e s n i c e}=19$ )

\section{Analýza pro-environmentálního chování žáků}

Stěžejní část dotazníku obsahovala tvrzení zjištéující, jakým způsobem je ovlivňováno konečné pro-environmentální chování žáků. Tato část dotazníku byla navržena na základě modelu TPB, který byl rozšířen o faktory vycházející z metody NAM.

Inspirace tímto složeným modelem vychází ze studie (Esfandiar a kol., 2020), ve které výzkumníci oba modely pro účely environmentálně zaměřeného výzkumu $s$ úspěchem sloučili. $V$ rámci zmiňované studie byl využit model TPB $\vee$ upravené podobě (model pracoval s konkrétním chováním, které respondenti $v$ dotazníku uvedli, namísto běžně užívaných intencí k určitému chování) a z modelu NAM byly využity dva faktory zjišt́ující uvědomění si důsledků chování a osobní normy. 
V prípadě našeho výzkumného modelu, byl taktéž použit upravený model TPB pracující se skutečným (resp. respondenty deklarovaným) pro-environmentálním chováním a dále byl přidán samostatný faktor z metody NAM - uvědomění si důsledků chování. Osobní normy byly v rámci našeho výzkumu sloučeny s postoji $\mathrm{k}$ danému chování. Otázky těchto dvou indikátorů vykazovaly značnou podobnost (ve svém znění), která byla následně potvrzena i při jejich vyhodnocování. Tyto dva faktory nesplňovaly podmínku diskriminační validity (Fornell - Larckerovo kritérium). Korelace mezi nimi byla př́liš vysoká s hodnotami kolem 0,8 a stejně tak hodnoty cross-loadings mezi jednotlivými otázkami a faktory poukazovaly na značnou podobnost faktorů.

Témata této části výzkumu pokrývala širší spektrum postojů a kategorií chování zahrnující tř́dění odpadu, nakládání s odpadem v přírodě, plýtvání jídlem, minimalizace odpadu obecně, uvědomělé spotřebitelské chování, hospodaření s vodou a elektřinou a podobně. Cílem této části bylo prozkoumání obecných skupin faktorů, které mají na konečné pro-environmentální chování žáků největší vliv.

Obrázek níže (Obrázek 1) zobrazuje podobu našeho výzkumného modelu a předpokládané vztahy mezi jednotlivými faktory, které byly vytvořeny na základě jednotlivých hypotéz.

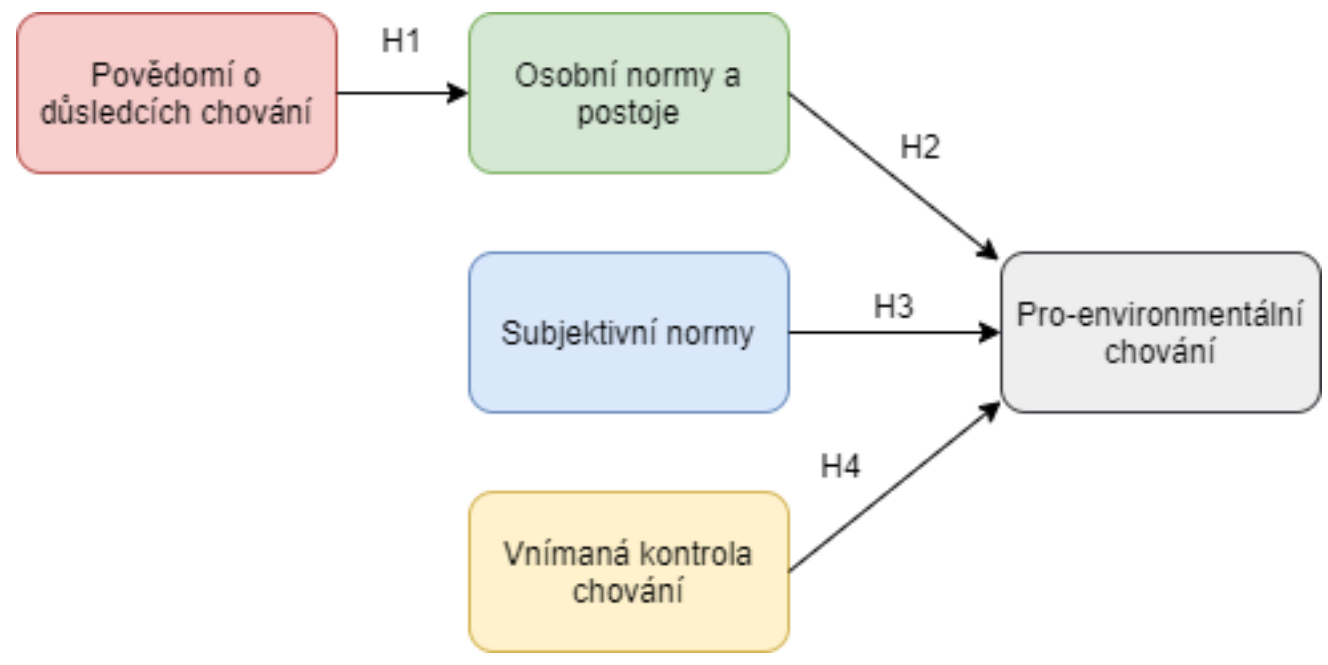

Obrázek 1: Výzkumný model

Na začátku výzkumu jsme si stanovili následující hypotézy:

H1: Povědomí o důsledcích chování (PDCH) má pozitivní vliv na osobní normy a postoje vưči proenvironmentálnímu chování (ONP).

H2: Osobní normy a postoje (ONP) vůči pro-environmentálnímu chování mají pozitivní vliv na proenvironmentální chování (PECH).

H3: Subjektivní normy (SN) mají pozitivní vliv na pro-environmentální chování (PECH).

H4: Vnímaná kontrola chování (VKCH) má pozitivní vliv na pro-environmentální chování (PECH).

Při stanovování hypotéz $\mathrm{H} 2, \mathrm{H} 3$ a $\mathrm{H} 4$ jsme vycházeli z podoby modelu TPB, který pracuje $s$ predpokladem, že právě uvedené kategorie proměnných (osobní postoje, subjektivní normy a vnímaná kontrola chování) mají potenciál ovlivnit intence $\mathrm{k}$ určitému chování, respektive $v$ prípadě našeho upraveného modelu prímo konečné pro-environmentální chování. $V$ př́padě hypotézy $\mathrm{H} 1$ jsme předpokládanou závislost stanovili na základě modelu NAM, který předpokládá, že určité faktory ( $v$ našem prípadě povědomí o důsledcích daného chování) mohou přispívat $\mathrm{k}$ aktivaci osobních norem. 
Respondenti odpovídali v této části výzkumu celkem na 66 otázek, respektive uváděli míru svého souhlasu/nesouhlasu na čtyřstupňové Likertově škále ( 1 =rozhodně souhlasím, $4=$ rozhodně nesouhlasím).

Navržené hypotézy byly testovány pomocí metody PLS-SEM (Partial Least Squares Structural Equation Modeling) v programu SmartPLS 3. Metoda PLS-SEM byla zvolena na základě doporučení studie Hair a kol. (2019), která uvádí uplatnění této metody v př́padech, kdy se jedná o testování teoretického rámce z predikční perspektivy, když strukturální model vykazuje prvky značné složitosti a zahrnuje více indikátorů a uplatňuje se také $v$ prípadě průzkumného šetření pro vývoj daného modelu nebo teorie a to i v př́padě, že výzkum disponuje malou velikostí vzorku. Reliabilita a validita vytvořeného modelu je uvedena $v$ tabulce 1 .

\begin{tabular}{|l|l|l|l|l|}
\hline & Cronbachovo alfa & rho_A & Složená reliabilita & AVE \\
\hline Osobní normy a postoje & 0,871 & 0,877 & 0,901 & 0,567 \\
\hline Povědomí o důsledcích chování & 0,725 & 0,796 & 0,819 & 0,482 \\
\hline Pro-environmentální chování & 0,658 & 0,661 & 0,784 & 0,422 \\
\hline Subjektivní normy & 0,680 & 0,714 & 0,791 & 0,436 \\
\hline Vnímaná kontrola chování & 0,698 & 0,702 & 0,800 & 0,403 \\
\hline
\end{tabular}

Tabulka 1: Reliabilita a validita modelu

Hodnoty vyjadřující Cronbachovo alfa se v našem př́padě pohybují od 0,658 do 0,871 . Hair (2021) uvádí požadovanou hodnotu ukazatele zjištujíći reliabilitu výzkumu 0,7 a více, nicméně hodnoty nad 0,6 považuje za akceptovatelné. Hodnoty AVE (average variance extracted) by dle studie Hair (2021) měly být větší než 0,5, nicméně jak uvádí Fornell a Larcker (1981), pokud jsou hodnoty složené reliability vyšší než 0,6 , konvergentní validita daného modelu je adekvátní i při hodnotách AVE $\geq 0,4$.

Hair (2021) dále uvádí doporučení týkající se hodnot složené reliability, které by měly být $\geq$ 0,7, což je $v$ našem prípadě splněno bez výhrad. Hodnoty složené reliability se pro náš model pohybují mezi 0,714 a 0,901.

Dále všechny ukazatele VIF (Variance Inflated Factor) dosahují hodnot menších než 5, z čehož vyplývá, že multikolinearita není problémem našeho modelu (Hair, 2021).

\begin{tabular}{|l|l|l|l|l|l|}
\hline Hypotéza & Vztah faktorů & $\beta$ koeficient & Směrodatná odchylka & t-hodnoty & $p$-hodnoty \\
\hline H1 & PDCH $\rightarrow$ ONP & 0,628 & 0,100 & 6,308 & 0,000 \\
\hline H2 & ONP $\rightarrow$ PECH & 0,482 & 0,089 & 5,439 & 0,000 \\
\hline H3 & SN $\rightarrow$ PECH & 0,216 & 0,120 & 1,798 & 0,073 \\
\hline H4 & VKCH $\rightarrow$ PECH & 0,231 & 0,110 & 2,102 & 0,036 \\
\hline
\end{tabular}

Tabulka 2: Testování hypotéz

$\checkmark$ tabulce 2 je pak možné nalézt hodnoty týkající se testování jednotlivých hypotéz. Pro hypotézy $\mathrm{H} 1, \mathrm{H} 2$ a H4 platí, že $\mathrm{p}$ hodnota je menší než předem zvolená hladina významnosti $\mathrm{p}=0,05$ a hypotézy tedy můžeme potvrdit. Hypotézu H1 a H2 můžeme dokonce potvrdit na $99 \%$ hladině významnosti.

Hypotézu H3, která vyjadřuje pozitivní vliv subjektivních norem na pro-environmentální chování, na zmíněné $95 \%$ hladině významnosti však potvrdit nemůžeme. Můžeme ji ale potvrdit na $90 \%$ hladině významnosti. 
$\beta$ koeficient vyjadřující míru korelace mezi jednotlivými faktory, poukazuje na nejtěsnější vztah mezi povědomím o důsledcích chování a osobními normami a postoji. Nezanedbatelná míra korelace je pozorovatelná taktéž $v$ prípadě osobních norem a postojů a jejich vlivu na pro-environmentální chování.

V tabulce není uveden, nicméně stojí za zmínku také nepřímý efekt vznikající $v$ prípadě $\mathrm{PDCH} \rightarrow \mathrm{PECH}$. Směrodatná odchylka $v$ tomto prípadě nabývá hodnot $\sigma=0,074$, $\mathrm{t}$-hodnota je rovna $\mathrm{t}=4,109$ a $\mathrm{p}$-hodnota $\mathrm{p}<0,001$.

Veškeré zmíněné vztahy je možné dohledat v grafickém znázornění modelu (Obrázek 2), který obsahuje hodnoty $\beta$, a tedy míru korelace mezi jednotlivými faktory.

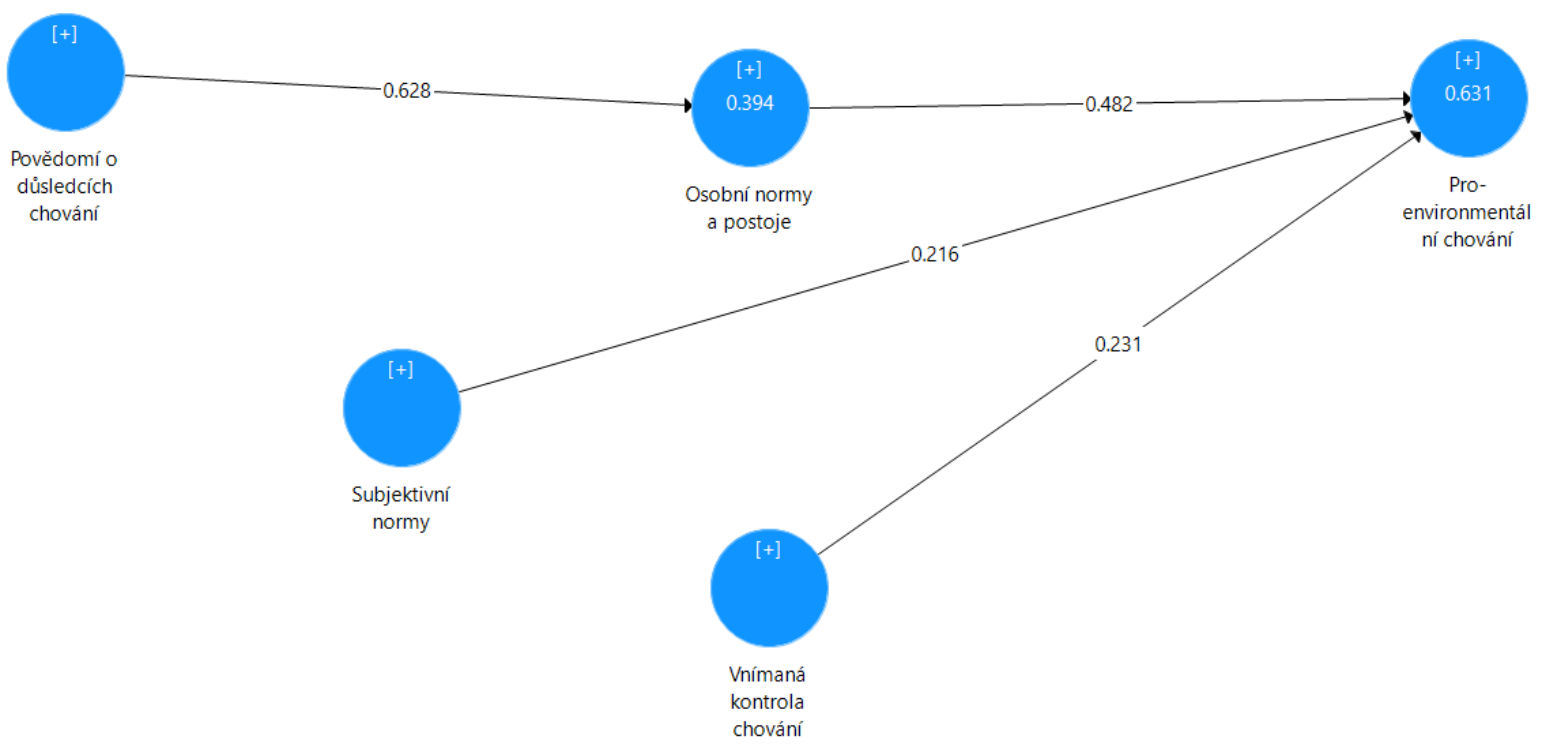

Obrázek 1: Grafické znázornění korelací v modelu

\section{Výsledky a diskuze}

Výsledky ukazují, že žáci mají relativně dobrý přehled o současných environmentálních problémech a dle odpovědí v dotazníku projevují zájem se o těchto tématech dozvídat v rámci environmentálního vzdělávání více informací. Žákům nejsou cizí ani velmi aktuální témata $v$ této oblasti, $i$ když výzkum poukazuje také na fakt, že nejnovější témata nejsou do vzdělávacích plánů zařazována $v$ takové míře a s rychlostí, jaká by danému vývoji odpovídala. Žáci dle výsledků považují za uspokojivější tu část environmentálního vzdělávání, která se věnuje nakládání s odpadem, tedy především správnému třídění odpadu. $V$ ostatních oblastech považuje většina žáků environmentální vzdělávání za nedostatečné a uvítali by, kdyby je škola v tomto ohledu vzdělávala více. Tato zjištění podporuje i studie analyzující stav environmentální výchovy v České republice, kterou vedl Činčera a kol. (2009). Ta poukazuje na fakt, že současná podoba environmentální výchovy nedrží krok s rychlým vývojem stavu životního prostředí a vědění v této oblasti. Environmentální výchova se podle zjištění studie věnuje stále stejným a ověřeným tématům jako je třídění odpadu a aktuální témata zařazuje do výuky s nedostatečnou rychlostí a nereaguje tak dostatečně na vývoj $v$ této oblasti. Také šetření České školní inspekce provedené ve školním roce 2019/2020 ukázalo, že žáci se s některými současnými environmentálními tématy (př́kladem byla klimatická změna) setkávají spíše v menší míre a nejsou s tímto stavem spokojeni. Žákům chybí kritická diskuze o daných tématech a podle svých slov nemá většina žáků vliv na to, jaká témata by se v rámci environmentálního vzdělávání mohla probírat. 
Tato zjištění nás proto nutí k zamyšlení, jaký zdroj informací umožňuje žákům (i přes pomalý rozvoj environmentálního vzdělávání) získávat přehled o nejaktuálnějším dění v oblasti environmentální problematiky. Zdrojem nejaktuálnějších informací o této tematice může být internet a sociální sítě, které pro získávání informací v této oblasti využívá 82 \% všech respondentů. S rozvojem moderních technologií zcela jistě roste vliv těchto médií a již se nyní se stává otázka propojení digitálních technologií s dosavadními formami výuky velmi diskutovaná. S rozvojem online vzdělávání a celkového posunu některých aktivit do online prostředí, které s sebou přinesla současná epidemiologická situace, bude řešení této otázky pro budoucí rozvoj vzdělávání pravděpodobně stěžejní. Takové stanovisko zastává například také Gleason a Gillern (2018), kteří se ve své studii zamýšlí nad dalšími možnostmi vzdělávání z hlediska propojení s moderními technologiemi a sociálními sítěmi a uvádí, že bude velmi důležité, aby byl v rámci vzdělávání nalezen způsob, jak přenést některé komunikační prvky z online prostředí do prostředí školního vzdělávání. Učitelé se postupem času budou pravděpodobně více zapojovat do online prostředí, kde budou se žáky v rámci výuky interagovat.

Vliv sociálních sítí na environmentální uvědomění potvrzuje napríklad Petrović a kol. (2012). V této studii bylo prokázáno, že sociální sítě využívané při environmentálním vzdělávání měly na studenty značný vliv. Studenti si při využití sociálních sítí v rámci environmentální výchovy rychleji a lépe osvojovali vhodné pro-environmentální návyky a ty u nich pak také výrazně déle přetrvávaly i po skončení výuky.

Výsledky našeho výzkumu však také poukazují na značný vliv školy, která je stále pro velkou část žáků jedním z hlavních zdrojů informací o environmentálních tématech a $z$ toho důvodu je jistě vhodné potenciálu školního vzdělávání v tomto směru vhodně využívat.

Žáci uváděli, že informace týkající se environmentálních témat se dozvídají napříč různými předměty výuky, což odpovídá současné koncepci environmentální výchovy jako průřezového tématu. Jak uvádí Činčera (2017), environmentální výchova již není chápána pouze jako podoblast př́rodopisu/biologie, ale jako oblast, která v sobě integruje humanitní i př́rodovědnou složku. Takový stav věci umožňuje, aby se environmentálnímu vzdělávání věnovali žáci v širokém spektru předmětů, což s sebou ale může nést určitou roztřištěnost v naplňování cílů environmentálního vzdělávání a existence značných rozdílů mezi žáky jednotlivých tř́idš̌kol v environmentálních znalostech.

Sukma a kol. (2020) ve své studii uvádí, že vzhledem k proměnám koncepce environmentálního vzdělávání a různorodým způsobům jeho zařazování do vzdělávacího procesu, záleží konečná podoba environmentální výchovy na konkrétním pedagogovi. Ten má často rozhodující roli $v$ tom, jakým konkrétním tématům se bude ve výuce věnovat a do jakých podrobností s nimi bude žáky seznamovat. Stěžejním předpokladem pro efektivní rozvoj environmentálního vzdělávání je proto kvalitní a pro-environmentálně zaměřené vzdělávání budoucích a současných pedagogů. $V$ takových prípadech často existují značné rozdíly mezi žáky jednotlivých tříd/škol v environmentálních znalostech.

Dalším tématem, které se vyskytlo mezi odpověd'mi respondentů byla nespokojenost s př́stupem školy k určitým tématům týkajícím se pro-environmentálního chování. Žáci uváděli, že jsou např́ílad nespokojeni s nadužíváním obalových materiálů a plýtváním jídlem v př́padě svačin a obědů ve školách. Může se obecně jednat o problémy na lokální úrovni, kterým škola nepřikládá takovou váhu, i když obecně žáky s globálními environmentálními tématy seznamuje. Ve své práci takový poznatek uvádí Činčera (2017), který poukazuje na fakt, že současná environmentální výchova je laděná více globálně a nedostatečně se zaměřuje na témata, která se vyskytují v př́mém okolí žáků, tedy na témata lokálního charakteru. Témata, která jsou žákům blízká a prímo se jich dotýkají, by měla být v rámci environmentálního vzdělávání využívána výrazně více, protože jedině tak budou mít žáci možnost vidět príklady řešení environmentálních problémů $v$ prímé praxi a budou si díky tomu moci uvědomit dopady svého vlastního chování na rozsáhlejší globální problémy.

Jak již bylo zmíněno v kapitole o podpoře vztahu žáků k prrírodě ze strany školy, řada studií potvrzuje pozitivní vliv venkovních aktivit $v$ průběhu vzdělávacího procesu na následné environmentální uvědomění (Bell a Dyment, 2008, Dyment, 2005, Emel a kol., 2015). V př́ípadě naší studie 
téměř $70 \%$ žáků uvedlo, že pobyt v př́rodě v rámci vyučování je pro ně velmi výjimečnou událostí. Větši rozdíly budou pravděpodobně existovat $v$ prípadě srovnání alternativních a tradičních škol, protože alternativní školy se na pohyb v prírodě a outdoorové aktivity obecně více zaměřují (Sokolíková, 2019). Otázkou zůstává, do jaké míry jsou skrze venkovní aktivity ovlivněny postoje a pro-environmentální žáků, zvláště pokud se budeme zaměřovat na žáky 3 . stupně vzdělávání, u kterých byl nebo nebyl již vztah k př́rodě vybudován v nižším věku. Studie Jose a kol. (2017) nicméně prokázala jasný pozitivní vliv na zlepšení výsledků environmentálního vzdělávání při využití outdoorových aktivit, a tak si jistě tato oblast zaslouží v budoucnu podrobnější prozkoumání korelace mezi mírou zařazování outdoorových aktivit do environmentálního vzdělávání a následnými pro-environmentálními postoji a chováním.

Analýza faktorů a míry jejich vlivu na pro-environmentální chování ukázala, že nejvíce chování žáků $v$ tomto ohledu ovlivňují jejich vlastní postoje a normy, na něž má signifikantní vliv povědomí o důsledcích jejich chování. Taktéž chování žáků ovlivňuje vnímaná kontrola chování, tedy pocit, zda je pro ně dané chování uskutečnitelné bez větších vnitřních nebo vnějších překážek. Signifikantní vliv nebyl prokázán v př́padě subjektivních norem, které poukazují na míru vlivu, který mají na respondenty blízké osoby, tedy rodina, přátelé nebo obecně lidé, kteří jsou pro žáky určitým vzorem. Ovlivňovat by respondenty mohli nepř́mo svým vlastním chováním $v$ této oblasti nebo cíleně skrze rady a doporučení. $V$ našem výzkumu nebyla potvrzena na hladině $95 \%$ hypotéza předpokládající korelaci mezi subjektivními normami a pro-environmentálním chováním.

$\checkmark$ českém prostředí se nám nepodařilo nalézt obdobné studie zabývající se tímto tématem (za předpokladu využití obdobného modelu) pro srovnání našich výsledků. výsledky zahraničních studií zabývajících se analýzou vlivů na pro-environmentální chování nebo intence k tomuto chování se mezi sebou často liší. Studie využívají modely stejně jako $v$ našem prípadě $v$ různých úpravách tak, aby co nejlépe vyhovovaly jejich potřebám. Niaura (2013) např́klad využívá ve své studii zabývající se analýzou faktorů majících vliv na pro-environmentální chování proměnnou představující sociální tlak okolí, do kterého zařazuje napríklad i vliv osob z respondentova okolí. Výsledná korelace mezi sociálním tlakem okolí a intencemi k pro-environmentálnímu chování byla nízká a výsledky se $v$ tomto případě bliží našemu zjištění.

Stejně tak studie Xu a kol. (2018) zkoumající vlivy na environmentální uvědomění nenalezla signifikantní vliv subjektivních norem na environmentálně odpovědné chování.

Naopak studie Esfandiar a kol. (2020) signifikantní vliv subjektivních norem na konečné proenvironmentální chování potvrdila. Naše výsledky se však se zmíněnou studií v mnoha ohledech shodují, napríklad $v$ nejvyšší míře korelace mezi osobními normami a pro-environmentálním chováním následované mírou korelace mezi vnímanou kontrolou chování a pro-environmentálním chováním. Taktéž zcela nejvyšší míra korelace stejně jako v našem prípadě nastala mezi povědomím o důsledcích chování a osobními normami. Důvodem, proč se naše výsledky liší v potvrzení/nepotvrzení hypotézy $\mathrm{H} 3$, která popisuje vliv subjektivních norem na pro-environmentální chování může být např́klad odlišná geografická oblast provedení našeho výzkumu. Jak uvádí i Esfandiar a kol. (2020), tyto výsledky mohou být velmi silně ovlivněny fenoménem, který popisuje ve své práci Hofstede (2001), a sice že lidé různých národností mají odlišné zvyky, návyky a tendence k určitému způsobu chování. Hofstede je popisuje vždy v rámci dvou polarit jako je např́klad dlouhodobá nebo krátkodobá orientace společnosti, zdrženlivost nebo požitkářství nebo pro naši otázku zásadní inklinace $\mathrm{k}$ individualismu nebo kolektivismu. Češi mají obecně o něco větší tendenci $\mathrm{k}$ individualismu než země východu, kde byla studie provedena a kde jsou obyvatelé orientováni více na kolektivistické pojetí.

Jak vyplývá z našich výsledků a potvrzují to i některé další zmíněné výzkumy, nejvíce proenvironmentální chování ovlivňují normy a postoje jedince. Ty jsou pak silně ovlivňovány skrze povědomí o důsledcích chování. Právě na tyto determinanty konečného pro-environmentálního chování bychom proto měli cílit skrze efektivní environmentální vzdělávání. 
Představený výzkum je výzkumem pilotním, z čehož vyplývají zjevné limity týkající se zejména malého počtu respondentů a $s$ tím spojené nedostatečné reprezentativnosti vzorku. Odhaluje nicméně některá zjištění, která si zasluhují zkoumání na větším vzorku respondentů a napomáhá zlepšení stávajícího výzkumného modelu pro budoucí šetření.

\section{Závěr}

Environmentální vzdělávání zcela jistě patři mezi obory, které v současnosti prochází rozsáhlým vývojem v reakci na důležitost dalšího udržitelného rozvoje životního prostředí. Jak ukázal náš výzkum, žáci obecně volají po změnách v oblasti environmentálního vzdělávání a uvítali by častější zařazování této problematiky do výuky za současného rozšiřování a inovování stávajících environmentálních témat, se kterými jsou ve škole seznamováni. České školství v tomto ohledu není rozhodně obsahově jednotné a zařazování environmentálních témat do výuky obecně záleží z velké části na konkrétních vyučujících a jejich vnímání důležitosti dané problematiky.

Věříme, že jasná koncepce environmentální výchovy by umožnila využít potenciál environmentálního vzdělávání výrazně lépe a napomohla by rozsáhlejšímu ovlivnění pro-environmentálního chování budoucích generací. Tento cíl (tedy ovlivnění environmentálního uvědomění) by se měl vzhledem k vývoji současné situace $v$ oblasti ochrany životního prostředí dostat do popředí, a právě s ohledem na něj by mělo být environmentální vzdělávání koncipováno.

Zde je však důležité si uvědomit nepostradatelnost lokálního výzkumu v této oblasti. Výsledky výzkumů, které se věnovaly analýze faktorů ovlivňujících environmentální uvědomění, se i v prípadě použití podobných výzkumných modelů a nástrojů často $v$ určitých ohledech velmi liší. Důvodů může být mnoho, avšak zcela zřejmé je, že společnost se v různých geografických oblastech odlišuje a z toho důvodu nejsou obecná zjištění aplikovatelná všude se stejným účinkem. Vzhledem k tomu, že naší snahou by $v$ rámci environmentálního vzdělávání mělo být ovlivňování environmentálního uvědomění, a především pak pro-environmentálního chování, musíme právě tyto rozdíly mezi různými společnostmi uvažovat a uvědomovat si, jaká koncepce tohoto vzdělávání bude vzhledem k psychologickému obrazu naší společnosti nejvhodnější právě pro Českou republiku. Zahraniční výzkumy by tak pro nás měly být $v$ tomto ohledu spíše inspirací, nikoliv návodem pro plánování podoby našeho environmentálního vzdělávání.

K žákům se informace o environmentálních problémech a katastrofách dostávají rychle skrze internet a další média, což je zjevně důsledek období hyperkonektivity, ve kterém se globální společnost nachází.

Školy ovšem budou stále více nuceny na tento vývoj reagovat, se žáky daná témata $v$ rámci environmentálního vzdělávání diskutovat a pomáhat žákům nalézat možnosti, kterými oni sami budou moci další vývoj věcí ovlivnit. Jak naznačují výsledky našeho výzkumu, stěžejní bude skrze tuto práci ovlivňovat postoje a normy žáků a bude zapotřebí budovat jejich povědomí o důsledcích jejich vlastního chování.

Předpokládáme, že další plánovaný výzkum $v$ této oblasti přinese podrobnější odpovědi na některé otázky týkající se analýzy determinantů pro-environmentálního chování a taktéž rozkryje některé konkrétní možnosti pro budoucí směřování environmentálního vzdělávání tak, aby toto vzdělávání dokázalo více využít svůj potenciál pro další udržitelný rozvoj. 


\section{Literatura}

- Ajzen, I. (1991). The theory of planned behavior. Organizational behavior and human decision processes, 50(2), 179-211. . https://doi.org/10.1016/0749-5978(91)90020-T

- Arı, E., \& Yılmaz, V. (2017). Effects of environmental illiteracy and environmental awareness among middle school students on environmental behavior. Environment, development and sustainability, 19(5), 1779-1793 https://doi.org/10.1007/s10668-016-9826-3

- Ärlemalm-Hagsér, E. (2013). Respect for Nature--A Prescription for Developing Environmental Awareness in Preschool. Center for Educational Policy Studies Journal, 3(1), 25-44. https://eric.ed.gov/?id=EJ1129478

- Bai, L., Sze, N. N., Liu, P., \& Haggart, A. G. (2020). Effect of environmental awareness on electric bicycle users' mode choices. Transportation research part $D$ : transport and environment, 82, 102320. https://doi.org/10.1016/j.trd.2020.102320

- Bell, A. C., \& Dyment, J. E. (2008). Grounds for health: the intersection of green school grounds and health-promoting schools. Environmental Education Research, 14(1), 77-90. https://doi.org/10.1080/13504620701843426

- Çokçaliskan, H., \& Çelik, Ö. (2017). Investigation of Pre-Service Classroom Teachers' Environmental Awareness and Attitudes. International Electronic Journal of Environmental Education, 7(2), 73-83. https://eric.ed.gov/?id=EJ1180988

- Činčera, J. (2005). Environmentální výchova. Ale jaká?. Pedagogická orientace, 15(3), 1724. https://journals.muni.cz/pedor/article/view/1029

- Činčera, J. (2017). Environmentální výchova jako průřezové téma: Podkladová studie. Praha: Núv.

- Činčera, J., Kroufek, R. (2021). Metodika hodnocení environmentální gramotnosti žáků.

- Činčera, J., Kulich, J., \& Gollová, D. (2009). Efektivita, evaluace a podpora programů environmentální výchovy. Envigogika, 4(2). https://doi.org/10.14712/18023061.39

- De Leeuw, A., Valois, P., Ajzen, I., \& Schmidt, P. (2015). Using the theory of planned behavior to identify key beliefs underlying pro-environmental behavior in high-school students: Implications for educational interventions. Journal of environmental psychology, 42, 128138. https://doi.org/10.1016/i.jenvp.2015.03.005

- Dyment, J. E. (2005). Green school grounds as sites for outdoor learning: Barriers and opportunities. International Research in Geographical \& Environmental Education, 14(1), 2845. https://doi.org/10.1080/09500790508668328

- Emekci, S. (2019). Green consumption behaviours of consumers within the scope of TPB. Journal of Consumer Marketing. https://doi.org/10.1108/JCM-05-2018-2694

- Emel, O. B., Ozdilek, H. G., \& YALCIN-OZDILEK, S. (2015). The short term effectiveness of an outdoor environmental education on environmental awareness and sensitivity of in-service teachers. International Electronic Journal of Environmental Education, 5(1), 1-19. https://doi.org/10.18497/iejee-green.03640

- Esfandiar, K., Dowling, R., Pearce, J., \& Goh, E. (2020). Personal norms and the adoption of pro-environmental binning behaviour in national parks: An integrated structural model approach. Journal of Sustainable Tourism, 28(1), 10-32.

https://doi.org/10.1080/09669582.2019.1663203 
- Ewert, A., Place, G., \& Sibthorp, J. (2005). Early-life outdoor experiences and an individuaI's environmental attitudes. Leisure Sciences, 27(3), 225-239.

https://doi.org/10.1080/01490400590930853

- Fornell, C., \& Larcker, D. F. (1981). Evaluating structural equation models with unobservable variables and measurement error. Journal of marketing research, 18(1), 39-50. https://doi.org/10.1177\%2F002224378101800104

- Fu, L., Sun, Z., Zha, L., Liu, F., He, L., Sun, X., \& Jing, X. (2020). Environmental awareness and pro-environmental behavior within china's road freight transportation industry: Moderating role of perceived policy effectiveness. Journal of Cleaner Production, 252, 119796. https://doi.org/10.1016/i.jclepro.2019.119796

- Gleason, B., \& Von Gillern, S. (2018). Digital citizenship with social media: Participatory practices of teaching and learning in secondary education. Journal of Educational Technology \& Society, 21(1), 200-212. http://www.jstor.org/stable/26273880

- Greaves, M., Zibarras, L. D., \& Stride, C. (2013). Using the theory of planned behavior to explore environmental behavioral intentions in the workplace. Journal of Environmental Psychology, 34, 109-120. https://doi.org/10.1016/j.jenvp.2013.02.003

- Hair Jr, J. F., Hult, G. T. M., Ringle, C. M., \& Sarstedt, M. (2021). A primer on partial least squares structural equation modeling (PLS-SEM). Sage publications.

- Hair, J. F., Risher, J. J., Sarstedt, M., \& Ringle, C. M. (2019). When to use and how to report the results of PLS-SEM. European business review. https://doi.org/10.1108/EBR-11$\underline{2018-0203}$

- Hofstede, G. (2001). Culture's consequences: Comparing values, behaviors, institutions and organizations across nations. Sage publications.

- Chawla, L. (1998). Significant life experiences revisited: A review of research on sources of environmental sensitivity. The Journal of environmental education, 29(3), 11-21. https://doi.org/10.1080/00958969809599114

- Chen, Y. (2020). An investigation of the influencing factors of Chinese WeChat users' environmental information-sharing behavior based on an integrated model of UGT, NAM, and TPB. Sustainability, 12(7), 2710. https://doi.org/10.3390/su12072710

- $\quad$ Long, Z., Wang, S., Gu, X., Sun, Y., Yu, J., \& Yang, J. (2020, February). Comparative Analysis of Adult and Adolescent Environmental Awareness and Intervention of Adolescent Environmental Awareness. In IOP Conference Series: Earth and Environmental Science (Vol. 446, No. 3, p. 032070). IOP Publishing. http://doi.org/10.1088/1755-1315/446/3/032070

- Matějček, T., \& Bartoš, J. (2012). Environmentální gramotnost učitelů a studentů učitelství. Envigogika, 7(2). https://doi.org/10.14712/18023061.75

- Nagra, V. (2010). Environmental education awareness among school teachers. The Environmentalist, 30(2), 153-162. https://doi.org/10.1007/s10669-010-9257-x

- Niaura, A. (2013). Using the theory of planned behavior to investigate the determinants of environmental behavior among youth. Environmental Research, Engineering and Management, 63(1), 74-81. https://doi.org/10.5755/j01.erem.63.1.2901

- Nisbet, E. K., Zelenski, J. M., \& Murphy, S. A. (2009). The nature relatedness scale: Linking individuals' connection with nature to environmental concern and behavior. Environment and behavior, 41(5), 715-740. https://doi.org/10.1177\%2F0013916508318748 
- Park, J., \& Ha, S. (2014). Understanding consumer recycling behavior: Combining the theory of planned behavior and the norm activation model. Family and consumer sciences research journal, 42(3), 278-291. https://doi.org/10.1111/fcsr.12061

- Petrović, N., Petrović, D., Jeremić, V., Milenković, N., \& Ćirović, M. (2012). Possible educational use of Facebook in higher environmental education. ICICTE 2012 proceedings, 355362. http://www.icicte.org/Proceedings2012/Papers/09-1-Petrovic.pdf

- Poškus, M. S. (2018). Investigating pro-environmental behaviors of Lithuanian university students. Current psychology, 37(1), 225-233. https://doi.org/10.1007/s12144-016-9506-3

- Rustam, A., Wang, Y., \& Zameer, H. (2020). Environmental awareness, firm sustainability exposure and green consumption behaviors. Journal of Cleaner Production, 268, 122016. https://doi.org/10.1016/i.jclepro.2020.122016

- Situmorang, R. P., \& Tarigan, S. D. (2018). Cultivating students' environmental awareness by creating bottle garden in school: A qualitative study. JPBI (Jurnal Pendidikan Biologi Indonesia), 4(3), 263-270. https://doi.org/10.22219/ipbi.v4i3.6785

- Sokolíková, E. (2019). Srovnání environmentálního uvědomění žáků z tradičních a alternativních základních škol. (Diplomová práce, Univerzita Karlova, Př́rodovědecká fakulta). https://dspace.cuni.cz/handle/20.500.11956/111100

- Straková, J., Simonová, J., \& Soukup, P. (2021). Vliv akademického optimismu na výsledky žáků středních škol. Orbis scholae, 14(3), 73-92. https://www.ceeol.com/search/articledetail?id=945926

- Sukma, E., Ramadhan, S., \& Indriyani, V. (2020, March). Integration of environmental education in elementary schools. In Journal of Physics: Conference Series (Vol. 1481, No. 1, p. 012136). IOP Publishing. http://doi.org/10.1088/1742-6596/1481/1/012136

- Svobodová, S. (2018). Konativní dimenze environmentální gramotnosti českých a slovenských žáků 2. stupně ZŠ. Envigogika, 13(2). https://doi.org/10.14712/18023061.578

- Svobodová, S., \& Kroufek, R. (2018). Možnosti využití škály MSELS pro testování environmentální gramotnosti na základních školách v České republice. Scientia in educatione, 9(2), 80-101. https://doi.org/10.14712/18047106.1210

- Wang, S., Wang, J., Zhao, S., \& Yang, S. (2019). Information publicity and resident's waste separation behavior: An empirical study based on the norm activation model. Waste management, 87, 33-42. https://doi.org/10.1016/i.wasman.2019.01.038

- Wihardjo, S. D., Hartati, S., Nurani, Y., \& Sujarwanta, A. (2017). The effects of green schooling knowledge level and intensity of parental guidance on the environmental awareness of the early age student. Educational Research and Reviews, 12(5), 251-257. https://doi.org/10.5897/ERR2015.2608

- Xu, L., Prybutok, V., \& Blankson, C. (2018). An environmental awareness purchasing intention model. Industrial Management \& Data Systems. https://doi.org/10.1108/IMDS-12-2017$\underline{0591}$

- Yang, M. X., Tang, X., Cheung, M. L., \& Zhang, Y. (2021). An institutional perspective on consumers' environmental awareness and pro-environmental behavioral intention: Evidence from 39 countries. Business Strategy and the Environment, 30(1), 566-575. https://doi.org/10.1002/bse.2638 
- Zhongguo, T. (2004). Establishing "green schools" and enhancing teachers and students' environmental awareness. Chinese Education \& Society, 37(3), 94-96.

https://doi.org/10.1080/10611932.2004.11031640

Autoři: Mgr. Eliška Sokolíková (eliska.sokolikova@student.pedf.cuni.cz), Ing. Jan Andreska, Ph.D. (ja.andreska@pedf.cuni.cz)

-oba autoři působí na katedře Biologie a environmentálních studií Pedagogické fakulty UK 